Lucrările Seminarului Geografic Dimitrie Cantemir

Vol. 45, October 2017, pp. 89-108

http://dx.doi.org/10.15551/lsgdc.v45i0.08

\title{
Disney cruise line environmental management. Part I: environmental policy and waste management on cruise itineraries
}

\author{
Valentina-Mariana Mănoiư ${ }^{1}$, Marina Antonescu' ${ }^{1}$ \\ ${ }^{1}$ University of Bucharest, Faculty of Geography, Romania.
}

To cite this article: Mănoiu, V.-M. \& Antonescu, M. (2017). Disney cruise line environmental management. Part I: environmental policy and waste management on cruise itineraries.

Lucrările Seminarului Geografic Dimitrie Cantemir, Vol. 45, pp. 89-108. DOI:

10.15551/lsgdc.v45i0.08

To link to this article: http://dx.doi.org/10.15551/lsgdc.v45i0.08 


\title{
DISNEY CRUISE LINE ENVIRONMENTAL MANAGEMENT. PART I: ENVIRONMENTAL POLICY AND WASTE MANAGEMENT ON CRUISE ITINERARIES
}

\author{
Valentina-Mariana Mănoiu ${ }^{1}$, Marina Antonescu ${ }^{2}$
}

\begin{abstract}
This article, which is part of a complex three-piece original work, presents in a logical manner the environmental policies of the Disney Cruise Line (DCL) company, as well as the cruise itinerary waste management plans for the enterprise's ships. In the follow-up paper, we will highlight waste management on the DCL ships and, in the third and final paper, we will analyse water management, including waste water, on board of these ships.

The purpose of this complex paper is to present the cruise ships' environmental impact prevention methods, by analysing the environmental policies and the main processes for dealing with the generated gaseous, liquid and solid waste (both along the cruise itineraries and on board); the study will focus on the DCL company, one of the world's leaders in entertainment, also known as one of the market's most environmentally-friendly players. The article, through its originality, will complement the relatively deficient scientific environmental studies available on this topic. The three-piece paper brings important information based on records and regulations introduced to ensure the proper use of the waste management system on both cruise routes and on board the ships, as well as details on the collection circuit, precautionary measures, risk factors, etc. looking to raise awareness and to optimize environment conservation procedures.
\end{abstract}

The paper is based on the analysis of the work carried out by in-house environmental personnel, the company's internal regulations, as well as the data and field observations collected by the environmental protection staff.

The paper's conclusion is that the DCL company aims to minimize the environmental impact of its cruise ships by focusing on new technologies, increasing energy efficiency, reducing the amount of generated waste, educating its employees and customers, while also promoting environmental conservation around the world. In 2013, DCL was declared the most environmentally-responsible cruise line. The company complies with all national and international environmental regulations and laws. The following potentially-polluting elements and activities, which can be considered to be pollution indicators, are strictly regulated by the DCL company in order to ensure that their environmental impact is as low as possible: discharging water and bio-residue (sludge) from the purification system; unloading treated bilge water; discharging ballast water; incineration; cleaning the incinerator chimney; incinerator ash; alkaline batteries; ship painting and polishing; used fuel; fuel emissions; opacity; washing the ship and the ship bridge; unloading food waste; unloading pool and spa water; fireworks.

The key words underpinning DLC's eco-friendly approach to its activity are: keeping records, monitoring, verification, awareness, constant communication.

Keywords: Disney Cruise Line, environmental policy, waste management, cruise itineraries

\footnotetext{
${ }^{1}$ University of Bucharest, Faculty of Geography, Bd. Nicolae Balcescu 1, 010041, Bucharest, Romania, valentina.mariana.manoiu@ gmail.com

${ }^{2}$ University of Bucharest, Faculty of Geography, Bd. Nicolae Balcescu 1, 010041, Bucharest, Romania, marina_antonescu@yahoo.com
} 


\section{Introduction}

Over the years, environmental issues have become a responsibility embraced by all people with an ecological consciousness, which led to a concerted worldwide effort. The development of a prevention strategy for ecological degradation implies the implementation of certain mechanisms and policies that allow both economic development and environmental preservation, setting a priority on the increase of environmental responsibility and economic efficiency, i.e. minimizing the costs for environmental damage mitigation actions caused by human intervention and consumption.

One of the key environmental policy objectives is the concept of sustainable development, which is a true transversal policy that embraces all other community policies, underlining the need for integrating environmental protection requirements into the definition and implementation of all global policies. Being responsible when it comes to environmental protection is key in creating an impeccable reputation and an outstanding trading value.

The present paper, as the first part of a complex three-piece original work, presents in a straight forward manner the environmental policies of the Disney Cruise Line (DCL) company, as well as the cruise itinerary waste management plans for the company's ships. In the follow-up paper, we will highlight the waste management processes on the DCL ships and, in the third and final paper, we will analyse water management, including waste water, on board of these ships.

The purpose of this complex paper is to present the cruise ship environmental impact prevention methods, by analysing the environmental policies and the main processes for dealing with the generated gaseous, liquid and solid waste (both along the cruise itineraries and on board); the study will focus on the DCL company, one of the world's leaders in entertainment, also known as one of the most environmentally-friendly players on the market. The article, through its originality, will complement the relatively deficient scientific environmental studies available on this topic (Loehr et al., 2003; Morehouse, Koch, 2003; Srinivasan, Swain, 2007; Burgin, Hardiman, 2011; Ulnikovic et al., 2012; Balaji et al., 2014; Kizielewicz, Lukovic, 2015; Lasserre, Tetu, 2015; Tichavska, Tovar, 2015; Papaefthimiou et al., 2016; Verna, Harris, 2016). The three-piece paper brings important information based on records and regulations introduced to ensure the proper use of the waste management system on both cruise routes and on board the ships, as well as details on the collection circuit, precautionary measures, risk factors, etc. looking to raise awareness and to optimize environment conservation procedures.

The paper is based on the analysis of the work carried out by the in-house environmental personnel, the company's internal regulations, as well as the data and field observations collected by the environmental protection staff.

\section{Describing the Disney Cruise Line Company}

The Walt Disney Company, known as Disney, founded by the animator who gave it its name, is one of the world's leading media, entertainment and production players. Disney Cruise Line is an enterprise affiliated with the Walt Disney Company (the Disney Cruise Line site). It was founded in 1996, initially under the name Magical Cruise Company Limited, based in London, UK, with its operational headquarters in Celebration, Florida (Disney Cruise Line site). 
The DCL is currently running four cruise ships (the Disney Cruise Line site): Disney Magic, Disney Wonder, Disney Dream, Disney Fantasy (Fig.1).

The Disney Magic cruise ship first sailed on July 30, 1998, while the Disney Wonder cruise ship was introduced to the public in august 1999. The two cruise ships are part of the medium range, with a width of $294 \mathrm{~m}$ and a length of $32 \mathrm{~m}$. Each ship has 875 rooms and a capacity of 2.800 passengers (2.000 clients and 800 employees). The two ships were designed differently, with numerous architectural elements and entertainment options for all age groups, as the company has a worldwide reputation for its thoughtful client satisfaction policies and its innovations in entertainment. The current cruise itineraries for these two ships connect Alaska, Bahamas, the Caribbean and Europe.

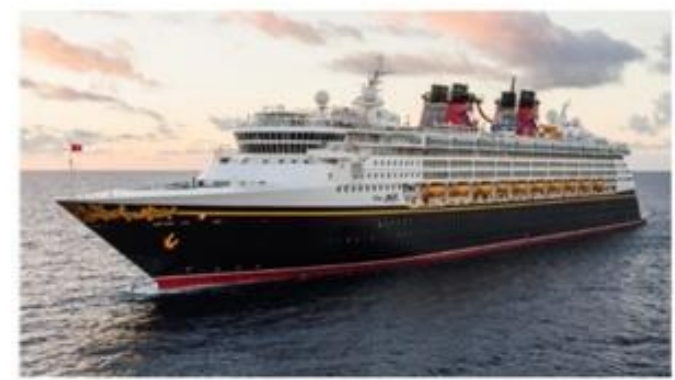

Disney Magic

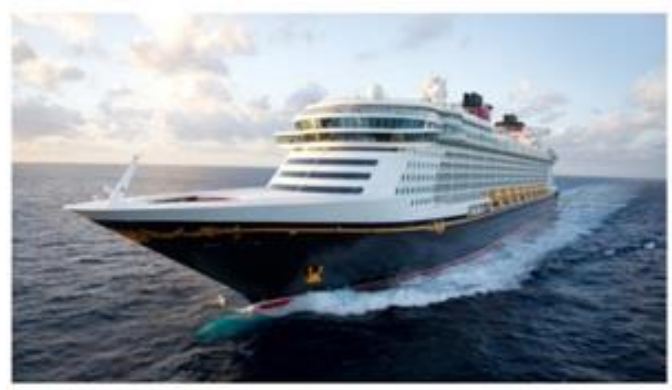

Disney Dream

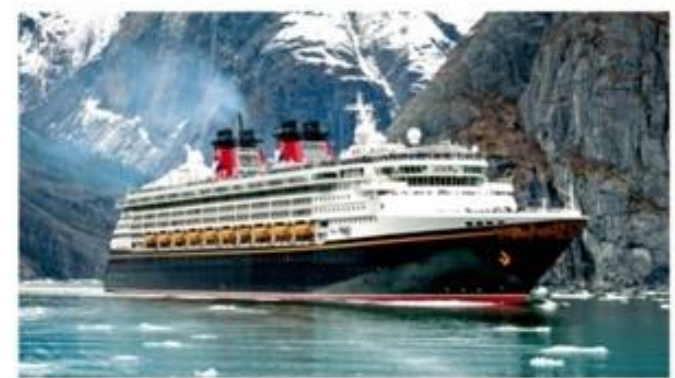

Disney Wonder

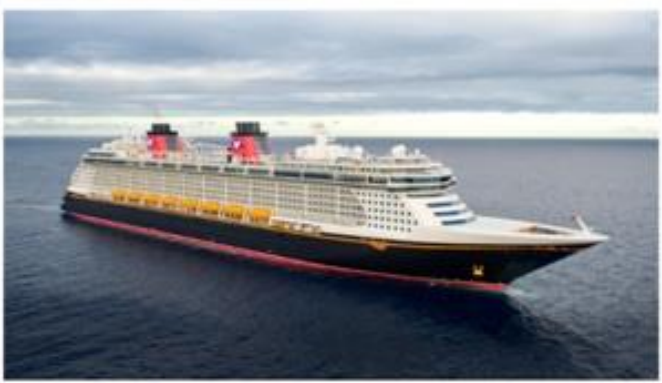

Disney Fantasy

Figure 1. The DCL Cruise Ships

(Photo source: the Disney Cruise Line site)

The Disney Dream and the Disney Fantasy cruise ships first sailed in January 2011 and January 2012. The two are part of the large cruise ship range, with a length of $339.5 \mathrm{~m}$ and a width of $36.8 \mathrm{~m}$. With a capacity of 5.700 passengers (4.000 clients and 1.700 employees), each ship has 1.250 rooms. Their current itineraries connect the Caribbean islands and the Bahamas.

\section{The environmental policies of the Disney Cruise Line Company}

Environmental management is an important pillar of Disney's vision of being the world's highest praised company. Disney aims to run its business and product creation in an ethical way, focusing on a sustainable and wise use of resource in order to protect the environment. 
The Walt Disney Company aims to establish and support the development of positive principles and values to protect the environment, especially with future generations in mind. In doing so, the company is committed to minimizing its global environmental impact, while encouraging and applying a responsible environmental education model for its members and employees, as well as for business partners and customers around the world.

Specifically, Disney proposes drastic measures for reducing water and energy use, as well as sustainable ecosystems, reducing greenhouse gas emissions and waste minimization. Through these actions, the company is looking to be a source of inspiration for public awareness in order to promote environmental sustainability (to understand the importance of the environment and to protect it). The company seeks to identify, measure and understand the direct and indirect impact of its operations on the environment, thus succeeding in developing innovative and realistic solutions to mitigate these effects. The company is also committed to regularly communicate its progress on environmental policy implementation and the achievement of its goals.

\subsection{The environmental policy of the $\mathrm{DCL}$ - general presentation}

The DCL environmental policy is available in the Safety Management System of the cruise line (Disney Cruise Line, 2016). The Vessel Sanitation Program (VSP) (US Department of Health and Human Services, 2011) is integrated throughout the DCL Environmental Policy. If the ship is located in an operational area governed by a different set of requirements, the references to the US VSP should be interpreted as referring to local standards. For example, in Europe, the references to the US VSP have to be interpreted as being part of the European Manual for Hygiene Standards and Communicable Disease Surveillance on Passenger Ships (EU SHIPSAN Act Joint Action 20122103) (EC-Directorate General for Health and Food Safety, 2016).

The Disney Cruise Line aims to ensure that all members of the organization are part of an ecological operation, respecting all applicable regulations and adhering to the DCL Environmental Policy. In 2013, the Disney Cruise Line was declared the most environmentally responsible cruise line (Elks, 2013). Also, in certain suitable places, the company posts notices on the importance of the measures taken to protect the environment: "Disney Cruise Line, the Captain and Chief Engineer, require you to follow all pollution laws, to the letter, at all times. Environmental Procedures or Equipment shall never be compromised to save money or time - not even temporarily. Report all pollution mistakes or problems to any ship's Officer and confirm that the Captain or Chief Engineer is also informed. We will support every Crew Member and Officer who immediately makes such a report of any malfunctioning equipment, or reports errors made in adhering to proper procedures." (Disney Cruise Line, 2016).

\subsection{DCL environmental goals}

The main environmental goals of the DCL Company are to respect all applicable regulatory requirements:

- The Bahamas Flag State requirements which incorporate most of the MARPOL provisions and other international conventions (UN-IMO, 2011).

- Port authority requirements of the DCL vessel in their areas of competence. 
- MARPOL - the DCL supports the objectives of the International Convention for the Prevention of Pollution from Ships (MARPOL) for eliminating the intentional marine oil/harmful substances and to minimize the accidental evacuation of these substances (UNIMO, 2011).

The DCL environmental policy involves the following:

- The company ships comply with the requirements of the Memorandum of Understanding (MOU) dating back to 12/6/2001 and agreed upon by the Cruise Lines International Association (CLIA) and the Environmental Protection Department (FEPD), which includes the Industrial Waste Management Standards that are not present in the current laws.

- General waste disposal policy - no pollutant should be disposed of in an improper manner and the authorized discharges should be reduced by waste minimization and recycling.

- Waste minimization - active involvement of employees in reducing the amount of material on board which could become waste. The company is working with its suppliers to convince them to consider purchasing products according to the amount of waste they will generate.

- Compliance with the Clean Air Act, the Clean Water Act of the US Environmental Protection Agency (EPA) and the National Pollutant Discharge Elimination System (NPDES) for accidental ship discharges (US EPA, 1972; US EPA, 1990; US EPA, 2013).

- The DCL works through several professional cruise associations in order to maintain a relationship with the regulatory community and to embrace the new technology in waste management.

- It is necessary to comply with the internal rules agreed upon in the DCL procedures and environmental policy which often incorporate the CLIA entertainment industry engagements.

- The DCL developed the Energy Efficient Management Plans on ships in accordance with MARPOL Annex VI Regulation 22 (UN-IMO, 2011). These plans are updated based on the requirements/needs or at least once a year. Through planning, implementation, monitoring and self-assessments, the ships can develop effective practices and procedures.

- In practice, the ships also follow the regulations established by other recognized authorities, such as the USCG (US Coast Guard), USPH (US Public Health) etc.

\subsection{Environmental responsibilities on board of the DCL ships}

The captain is responsible for the waste management procedures on board of the ships. He or she delegates this responsibility to all heads of departments on the ship. Each head of department is responsible for the waste handling operations in their sector and oversees the waste collection process, waste separation and its transportation to the waste processing area. The heads of departments need to make sure that their team members comply with the waste management procedures. Each department has the responsibility to reduce the amount of waste and to notify the environmental officer of any matter related to waste.

The environmental officer is responsible for the waste management operation and the maintenance of all documents in accordance with MARPOL. The garbage/waste managers are responsible for receiving, processing, storing and unloading all waste, recyclable objects and hazardous waste on or taken off the ship. They are also responsible for the day to day cleaning 
and maintenance of waste processing facilities on the ship. The environmental officer is the person responsible for giving the on-board environmental policy presentation to all crew members. In order to prevent pollution incidents, the environmental officer uses manuals and instructions specifically designed for this purpose. All training sessions attended by each crew member must be recorded.

The chief engineer is responsible for the maintenance and proper operation of the incinerators, the proper disposal of waste containing oil traces, as well as preventive maintenance work and repairing all waste-processing equipment.

The B mechanic is responsible for the daily incinerator work and its maintenance. He or she is also responsible for removing the ash from the incinerators and transporting it for storage.

All crew members are responsible for meeting the DCL's environmental requirements and policy. They need to be careful with all practices that can generate pollution - these include waste collection and the improper overboard discharges by on-board personnel (employees and clients), as well as continuous efforts to minimize waste and the risks associated with it on board the DCL ships. In order to reach these goals, the procedures concerning waste storage, use and disposal are followed to the letter.

\subsection{Environmental responsibilities of on-shore personnel}

The Operations First Vice-President is responsible for the proper handling and disposal of ship-generated waste and its discharge into port, at which point the land-based facilities take over.

The Operations First Vice-President delegates responsibilities to the following:

- The Marine and technical operations Vice-President is in charge of unloading oily waste and providing on-shore support for the proper maintenance and operation of the onboard waste management system.

- The Hotel Operations Vice-President is responsible for the purchase of goods and materials from ecological suppliers in order to minimize product packaging, supplying ships with recycling containers and purchasing products that reduce the amount of plastics introduced into the waste stream.

- The Entertainment and Shore Exploration Vice-President is responsible for the proper management of stage pyrotechnics.

- The Safety, Security and Environment VP - is responsible for facilitating growth and making sure waste management policies are implemented correctly.

\section{An overview of waste streams on the DCL itineraries}

\subsection{General provisions}

For all the waste streams on different itineraries, the distances are measured from the "nearest shore", a term which describes the baseline area where the measurement for the territorial sea begins, in accordance with international law (UN-IMO, 2011).

The waste categories that can be generated on board the DCL ships which must be managed on various itineraries are the following: 
Non-hazardous waste produced at hotel level

- Paper and plastics

- Food waste

- Glass

- Contaminated food/wet carton

- Canned food

These waste groups are the most common on board the ships and can be easily processed and disposed of, provided they have been appropriately separated from the source. After processing, the waste is properly stored as it awaits its transfer to land. Food waste can only be discharged overboard if the applicable requirements have been met.

\section{Recyclable materials}

- Aluminium boxes

- Lead-acid batteries

- Clean/dry carton

- Plastic bottles

- Scrap metal

- Toner cartridges

- Photographic processing silver

- White, compact clean paper

- Cooking oil

The recyclable materials are unloaded to shore and handed over to a recycling company or returned to the vendor. Recyclable materials must be separated according to the Waste Separation Standards and brought directly to the processing waste plant (Disney Cruise Line, 2016).

\section{Universal and dangerous waste}

- Chemicals

- Batteries (except alkaline and recyclable batteries)

- Used paint/diluents*

- Photographic waste

- Chemical cleaning waste

- Medical waste (bio-dangerous, pieces with sharp edges, pharmaceuticals)

- Mercury and fluorescent bulbs*

- Incinerator ash

- Used refrigeration appliances

- Aerosol cans*

- Industrial waste

- Pesticides

- Pyrotechnic products

* Universal waste refers to the on-board waste that can be classified as hazardous but can be treated, tested or monitored prior to disposal in order to verify that it is no longer hazardous, being labelled as Industrial Waste or Non-regulated waste (Universal Waste Site).

\section{Water/oil mixtures (oily water)}

- Oily water is the liquid collected in the bilge open spaces.

Waste oil/oil sludge

- Used lubricated oil

- Fuel sludge 
- Used cooking oil and fat

- Any other type of oily waste

\section{Domestic/grey water}

- Sink and shower waste water

- Laundry waste water

- Kitchen waste water

- Air conditioning and return water waste

- Spa salon waste water

\section{Black water}

- $\quad$ Toilet waste water

- Medical facility waste water

Compound emissions that impact air quality

- Nitrogen oxides (NOx)

- $\quad$ Sulphur oxides (SOx)

- Refrigerants

- Visible smoke

- Volatile Organic Compounds (COV)

Other operating systems that may have an impact on the environment

- Ballast water

- $\quad$ Swimming pool water

- Spa water

The Waste Stream Chart is a general overview of the company's various environmental laws and policies, as well as a source for the specific waste requirements mandatory on individual cruise ship itineraries. In the present paper, the Waste Stream Presentation for various itineraries was done using tables in order to facilitate the information structure and to allow a better browsing and understanding exercise.

\subsection{Alaska Waste Streams}

\begin{tabular}{|c|c|c|c|c|c|}
\hline \multicolumn{2}{|c|}{$\begin{array}{l}\text { Water discharge from the } \\
\text { purification system }\end{array}$} & \multicolumn{2}{|c|}{$\begin{array}{l}\text { Bio-waste from the } \\
\text { purification system (sludge) }{ }^{1}\end{array}$} & \multicolumn{2}{|c|}{$\begin{array}{l}\text { The treated bilge } \\
\text { water }^{1}\end{array}$} \\
\hline \multicolumn{2}{|c|}{$\begin{array}{l}\text { Discharge cannot be done at a } \\
\text { speed lower than } 6 \text { nodes. } \\
\text { Unloading is forbidden on the } \\
\text { Tracy river or in the Skagway } \\
\text { Port. }\end{array}$} & \multicolumn{2}{|c|}{$\begin{array}{l}\text { Discharge takes place at over } \\
12 \mathrm{NM} \text { (nautical mile) and at a } \\
\text { speed that is at least } 6 \text { nodes, } \\
\text { outside of Alaska waters. }\end{array}$} & \multicolumn{2}{|c|}{$\begin{array}{l}\text { Discharge takes place at } \\
\text { over } 12 \mathrm{NM} \text { and at a } \\
\text { speed that is at least } 6 \\
\text { nodes, outside of Alaska } \\
\text { waters }\end{array}$} \\
\hline $\begin{array}{l}\text { Ballast } \\
\text { water }^{1}\end{array}$ & Incinerator $^{2}$ & $\begin{array}{l}\text { Incinerator } \\
\text { chimney } \\
\text { cleaning }{ }^{1}\end{array}$ & Painting & & Opacity $^{2}$ \\
\hline $\begin{array}{l}\text { Discharge } \\
\text { is } \\
\text { forbidden } \\
\text { in Alaska } \\
\text { waters. }\end{array}$ & $\begin{array}{l}\text { Burning actions } \\
\text { are not allowed } \\
\text { at less than } \\
\text { 3NM from the } \\
\text { shore. }\end{array}$ & $\begin{array}{l}\text { The NPDES } \\
\text { VGP 2.2.23 } \\
\text { provisions must } \\
\text { be followed (US } \\
\text { EPA, 2013) }\end{array}$ & $\begin{array}{l}\text { Painting is all } \\
\text { ports, but onl } \\
\text { following spe } \\
\text { instructions o } \\
\text { available man } \\
\text { methods. }\end{array}$ & $\begin{array}{l}\text { ed in } \\
y \\
\text { ic } \\
\text { he best } \\
\text { ement }\end{array}$ & $\begin{array}{l}\text { Opacity cannot } \\
\text { go over } 20 \% \\
\text { for more than } \\
3 \text { minutes an } \\
\text { hour. }\end{array}$ \\
\hline
\end{tabular}


Observations:

${ }^{1}$ Alaska waters are defined in 18 AAC 70.005/2014 (The Alaska Department of Environmental Conservation-Division of Water, 2014)

${ }^{2}$ The opacity limits are recorded under 18 AAC 50.070/2014 (The Alaska Department of Environmental Conservation-Division of Air Quality, 2014)

\subsection{The waste streams in the Bahamas, the Caribbean and the Gulf of Mexico}

\begin{tabular}{|c|c|c|c|}
\hline \multicolumn{4}{|c|}{ 1. Washing the deck and the cruise ship } \\
\hline \multicolumn{2}{|l|}{ Using only water } & \multicolumn{2}{|c|}{$\begin{array}{l}\text { Using water or non-toxic, phosphate-free, } \\
\text { biodegradable cleaning products. }\end{array}$} \\
\hline \multicolumn{2}{|c|}{$\begin{array}{l}\text { Port (Country) } \\
\text { - } \text { Basseterre (Saint Kitts and Nevis) } \\
\text { - Grand Cayman (Cayman Islands) } \\
\text { - Tortola (British Virgin Islands) }\end{array}$} & \multicolumn{2}{|c|}{$\begin{array}{l}\text { Port (Country) } \\
\text { - Bridgetown (Barbados) } \\
\text { - Castaway Cay (Bahamas) } \\
\text { - Costa Maya (Mexico) } \\
\text { - Castries (SaintLucia) } \\
\text { - Cozumel (Mexico) } \\
\text { - Falmouth (Jamaica) } \\
\text { - Key West, Miami, Port Canaveral, San } \\
\text { - Juan, Saint Thomas (USA) } \\
\text { - St George's (Grenada) } \\
\text { - Sint Maarten (The Netherlands) } \\
\end{array}$} \\
\hline \multicolumn{4}{|c|}{ 2. Incinerator } \\
\hline $\begin{array}{l}\text { Cannot be used at a } \\
\text { distance smaller } \\
\text { than } 12 \mathrm{NM} \text { from } \\
\text { the shore }\end{array}$ & $\begin{array}{l}\text { Cannot be used at a } \\
\text { distance smaller than } 5 \\
\text { NM from the shore }\end{array}$ & $\begin{array}{l}\text { Cannot be used at a } \\
\text { distance smaller than } 3 \\
\text { NM from the shore }\end{array}$ & $\begin{array}{l}\text { Cannot be used in } \\
\text { the port. }\end{array}$ \\
\hline $\begin{array}{l}\text { Port (Country) } \\
\text { - } \text { Basseterre (Saint } \\
\text { Kitts and Nevis) } \\
\text { - } \text { Castries (Saint } \\
\text { Lucia) } \\
\text { - Falmouth } \\
\text { (Jamaica) } \\
\text { - Grand Cayman } \\
\text { (Cayman } \\
\text { Islands) }\end{array}$ & $\begin{array}{l}\text { Port (Country) } \\
\text { - St George's } \\
\text { (Grenada) }\end{array}$ & $\begin{array}{l}\text { Port (Country) } \\
\text { - } \text { Bridgetown } \\
\text { (Barbados) } \\
\text { - Key West, Miami, } \\
\text { Port Canaveral, San } \\
\text { Juan, Saint Thomas } \\
\text { (USA) }\end{array}$ & $\begin{array}{l}\text { Port (Country) } \\
\text { - Castaway Cay } \\
\text { (Bahamas) } \\
\text { - Costa Maya, } \\
\text { Cozumel } \\
\text { (Mexico) } \\
\text { - Nassau } \\
\text { (Bahamas) } \\
\text { - Sint Maarten } \\
\text { (The } \\
\text { Netherlands) } \\
\text { - Tortola (British } \\
\text { Virgin Islands) }\end{array}$ \\
\hline \multicolumn{4}{|c|}{ 3. Cleaning the cruise ship hull (body) } \\
\hline \multicolumn{2}{|c|}{ Check with the port agent } & Not allowed & $\begin{array}{l}\text { Follow the NPDES } \\
\text { VGP 2.2.23 policy } \\
\text { (US EPA 2013) }\end{array}$ \\
\hline \multicolumn{2}{|c|}{$\begin{array}{l}\text { Port (Country) } \\
\text { - Castaway Cay (Bahamas) } \\
\text { - Costa Maya, Cozumel (Mexico) }\end{array}$} & $\begin{array}{l}\text { Port (Country) } \\
\text { - Basseterre (Saint } \\
\text { Kitts and Nevis) } \\
\end{array}$ & $\begin{array}{l}\text { Port (Country) } \\
\text { - Key West, } \\
\text { Miami, Port } \\
\end{array}$ \\
\hline
\end{tabular}




\begin{tabular}{|c|c|c|c|}
\hline \multicolumn{2}{|c|}{$\begin{array}{l}\text { - Falmouth (Jamaica) } \\
\text { - Nassau (Bahamas) } \\
\text { - St George's (Grenada) } \\
\text { - Tortola (British Virgin Islands) }\end{array}$} & 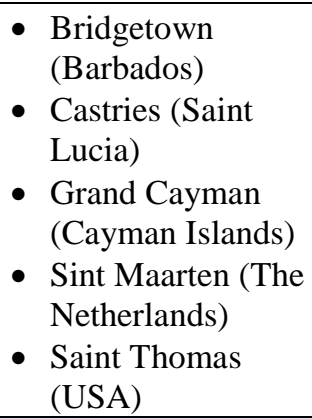 & $\begin{array}{l}\text { Canaveral, San } \\
\text { Juan (USA) }\end{array}$ \\
\hline \multicolumn{4}{|c|}{ 4. Sanding and painting } \\
\hline $\begin{array}{l}\text { Allowed. None of } \\
\text { the surfaces } \\
\text { touching water }\end{array}$ & $\begin{array}{l}\text { Check with the port } \\
\text { agent. Only small } \\
\text { surfaces. None of the } \\
\text { surfaces touching } \\
\text { water. }\end{array}$ & $\begin{array}{l}\text { Sanding is not } \\
\text { allowed. Painting - } \\
\text { check with the port } \\
\text { agent. Only small } \\
\text { surfaces. None of the } \\
\text { surfaces touching } \\
\text { water. }\end{array}$ & Not allowed. \\
\hline $\begin{array}{l}\text { Port (Country) } \\
\text { - Bridgetown } \\
\text { (Barbados) } \\
\text { - Castaway Cay } \\
\text { (Bahamas) } \\
\text { - Falmouth } \\
\text { (Jamaica) }\end{array}$ & $\begin{array}{l}\text { Port (Country) } \\
\text { - Nassau (Bahamas) } \\
\text { - Port Canaveral, } \\
\text { San Juan, Saint } \\
\text { Thomas (USA) } \\
\text { - Sint Maarten (The } \\
\text { Netherlands) }\end{array}$ & $\begin{array}{l}\text { Port (Country) } \\
\text { - Basseterre (Saint } \\
\text { Kitts and Nevis) } \\
\text { - Castries (Saint } \\
\text { Lucia) } \\
\text { - Key West, Miami } \\
\text { (USA) }\end{array}$ & $\begin{array}{l}\text { Port (Country) } \\
\text { - Costa Maya, } \\
\text { Cozumel } \\
\text { (Mexico) } \\
\text { - Grand Cayman } \\
\text { (Cayman } \\
\text { Islands) } \\
\text { - St George's } \\
\text { (Grenada) } \\
\text { - Tortola (British } \\
\text { Virgin Islands) }\end{array}$ \\
\hline
\end{tabular}

\begin{tabular}{|l|l|l|l|l|}
\hline Port & $\begin{array}{l}\text { Purification } \\
\text { system water } \\
\text { discharge }\end{array}$ & $\begin{array}{l}\text { Purification } \\
\text { system bio-waste } \\
\text { (lludge) }\end{array}$ & $\begin{array}{l}\text { Treated bilge } \\
\text { water }\end{array}$ & Food waste \\
\hline All ports & $\begin{array}{l}\text { Discharge takes } \\
\text { place at a distance } \\
\text { above 4NM. } \\
\text { Grand Cayman: the } \\
\text { discharge can only } \\
\text { take place at a } \\
\text { distance over 12 } \\
\text { NM. }\end{array}$ & $\begin{array}{l}\text { Discharge can } \\
\text { only take place at } \\
\text { a distance over 12 } \\
\text { NM, at a speed of } \\
\text { over 6 nodes. }\end{array}$ & $\begin{array}{l}\text { Discharge can } \\
\text { only take place } \\
\text { at a distance } \\
\text { over 12 NM, at } \\
\text { a speed of over } \\
6 \text { nodes. }\end{array}$ & $\begin{array}{l}\text { Discharge can } \\
\text { only take place } \\
\text { at a distance } \\
\text { over 12 NM, at } \\
\text { a speed of over } \\
6 \text { nodes. }\end{array}$ \\
\hline
\end{tabular}

Observation: Waste discharge and disposal procedures comply with MARPOL requirements (UN IMO, 2011). 


\subsection{Waste streams from the Baltic Sea, the UK and the North Sea}

\begin{tabular}{|c|c|c|c|}
\hline \multicolumn{4}{|c|}{ 1. Purification system water discharge } \\
\hline $\begin{array}{l}\text { Discharge can only take } \\
\text { place at a distance over } 4 \\
\mathrm{NM} \text {, at a speed of over } 6 \\
\text { nodes. }\end{array}$ & \multicolumn{2}{|c|}{$\begin{array}{l}\text { Discharge can only take place } \\
\text { at a distance over } 4 \text { NM, at a } \\
\text { speed of over } 6 \text { nodes. Barge } \\
\text { discharge option available. }\end{array}$} & $\begin{array}{l}\text { Discharge can only take } \\
\text { place at a distance over } 4 \\
\text { NM, at a speed of over } 6 \\
\text { nodes. While stationary in } \\
\text { port - the discharge is } \\
\text { carried out through port } \\
\text { connections. } \\
\end{array}$ \\
\hline $\begin{array}{l}\text { Port (Country) } \\
\text { - } \text { Dover, Liverpool, } \\
\text { Newcastle, Invergordon, } \\
\text { Greenock (The United } \\
\text { Kingdom) } \\
\text { - } \text { Dublin (Ireland) } \\
\text { - Saint Peter Port } \\
\text { (Guernsey) } \\
\text { - Akureyri, } \\
\text { - Reykjavik (Iceland) } \\
\text { - Alesund, Bergen, } \\
\text { Kristiansand, Oslo, } \\
\text { Stavanger, Geiranger } \\
\text { (Norway) } \\
\text { - Copenhagen (Denmark) } \\
\text { - Tallinn (Estonia) } \\
\text { - Kirkwall (Scotland) } \\
\text { - Vigo(Spain) }\end{array}$ & \multicolumn{2}{|c|}{$\begin{array}{l}\text { Port (Country) } \\
\text { - Le Havre (France) }\end{array}$} & $\begin{array}{l}\text { Port (Country) } \\
\text { - Helsinki (Finland) } \\
\text { - Stockholm (Sweden) }\end{array}$ \\
\hline \multicolumn{4}{|c|}{$\begin{array}{l}\text { * Saint Petersburg (Russia) - Before entering St. Petersburg Sea Traffic Management } \\
\text { (STM) area: discharge is stopped. All valves and exhaust valves must be sealed. While } \\
\text { stationary in port: discharge is done through special port connections. On departure, all tanks } \\
\text { must operate at no more than } 25 \% \text { of capacity. }\end{array}$} \\
\hline \multicolumn{4}{|c|}{ 2. Purification system bio-waste (sludge) ${ }^{1}$} \\
\hline \multicolumn{2}{|c|}{$\begin{array}{l}\text { Discharge can only take place at a distance } \\
\text { over } 12 \text { NM, at a speed of over } 6 \text { nodes: } \\
\text { Port (Country) } \\
\text { - Dover, Liverpool, Newcastle, } \\
\text { Invergordon, Greenock (The United } \\
\text { Kingdom) } \\
\text { - Reykjavik (Iceland) } \\
\text { - Bergen, Kristiansand, Oslo, Stavanger, } \\
\text { - Geiranger (Norway) } \\
\text { - Copenhagen (Denmark) } \\
\text { - Tallinn (Estonia) } \\
\text { - Virkwall (Scotland) } \\
\end{array}$} & \multicolumn{2}{|c|}{$\begin{array}{l}\text { Discharge can only take place at a distance } \\
\text { over } 12 \text { NM, at a speed of over } 6 \text { nodes. } \\
\text { While stationary in port - truck discharge } \\
\text { option available: } \\
\text { Port (Country) } \\
\text { - Dublin (Ireland) } \\
\text { - Akureyri (Iceland) } \\
\text { - Alesund (Norway) } \\
\text { - Helsinki (Finland) } \\
\text { - Stockholm (Sweden) }\end{array}$} \\
\hline
\end{tabular}




\begin{tabular}{|c|c|c|c|c|}
\hline \multicolumn{2}{|c|}{$\begin{array}{l}\text { Discharge can only take place at a distance } \\
\text { over } 12 \text { NM, at a speed of over } 6 \text { nodes. } \\
\text { There are no discharge facilities on shore: } \\
\text { Port (Country) } \\
\text { - Saint Peter Port (Guernsey) }\end{array}$} & \multicolumn{3}{|c|}{$\begin{array}{l}\text { Discharge can only take place at a distance } \\
\text { over } 12 \text { NM, at a speed of over } 6 \text { nodes. } \\
\text { Barge discharge option available: } \\
\text { Port (Country) } \\
\text { - Le Havre (France) }\end{array}$} \\
\hline \multicolumn{5}{|c|}{$\begin{array}{l}\text { * Saint Petersburg (Russia) - Before entering St. Petersburg Sea Traffic Management } \\
\text { (STM) area: discharge is stopped. All valves and exhaust valves must be sealed. While } \\
\text { stationary in port: discharge is done through special port connections. On departure, all tanks } \\
\text { must operate at no more than } 25 \% \text { of capacity. }\end{array}$} \\
\hline \multicolumn{5}{|c|}{ 3. Treated bilge water ${ }^{1}$} \\
\hline $\begin{array}{l}\text { Discharge can only take } \\
\text { place at a distance over } 12 \\
\mathrm{NM} \text {, at a speed of over } 6 \\
\text { nodes. }\end{array}$ & $\begin{array}{l}\text { Discharge ca } \\
\text { at a distance } \\
\text { speed of ove } \\
\text { stationary in } \\
\text { discharge op }\end{array}$ & & $\begin{array}{l}\text { e place } \\
\text { M, at a } \\
\text { While } \\
\text { k } \\
\text { ble. }\end{array}$ & $\begin{array}{l}\text { Discharge can only take } \\
\text { place at a distance over } 12 \\
\mathrm{NM} \text {, at a speed of over } 6 \\
\text { nodes. While stationary in } \\
\text { port - truck (capacity } 30 \mathrm{~m}^{3} \text { ) } \\
\text { discharge option available. }\end{array}$ \\
\hline $\begin{array}{l}\text { Port (Country) } \\
\text { - } \text { Dover, Liverpool, } \\
\text { Newcastle, Invergordon, } \\
\text { Greenock (The United } \\
\text { Kingdom) } \\
\text { - } \text { Dublin (Ireland) } \\
\text { - Le Havre (France) } \\
\text { - Saint Peter Port } \\
\text { (Guernsey) } \\
\text { - } \text { Akureyri, Reykjavik } \\
\text { (Iceland) } \\
\text { - Copenhagen (Denmark) } \\
\text { - Tallinn (Estonia) } \\
\text { - Kirkwall (Scotland) } \\
\text { - Vigo (Spain) } \\
\text { - Stockholm (Sweden) }\end{array}$ & $\begin{array}{l}\text { Port (Count } \\
\text { - Alesund, } 1 \\
\text { Kristiansa } \\
\text { Stavanger } \\
\text { (Norway) }\end{array}$ & $\begin{array}{l}\text { Sen, } \\
\text { Oslc } \\
\text { iran }\end{array}$ & & $\begin{array}{l}\text { Port (Country) } \\
\text { - Helsinki (Finland) }\end{array}$ \\
\hline \multicolumn{5}{|c|}{$\begin{array}{l}\text { * Saint Petersburg (Russia) - Before entering St. Petersburg Sea Traffic Management } \\
\text { (STM) area: discharge is stopped. All valves and exhaust valves must be sealed. }\end{array}$} \\
\hline \multicolumn{5}{|c|}{ 4. Incinerator } \\
\hline \multicolumn{5}{|c|}{ Incineration is forbidden at a distance under $12 \mathrm{NM}$ from shore. } \\
\hline \multicolumn{3}{|c|}{$\begin{array}{l}\text { Port (Country) } \\
\text { - } \text { Dover, Liverpool, Newcastle, Invergordon, } \\
\text { Greenock (The United Kingdom) } \\
\text { - } \text { Dublin (Ireland) } \\
\text { - Le Havre (France) } \\
\text { - Saint Peter Port (Guernsey) } \\
\text { - Akureyri, Reykjavik (Iceland) } \\
\text { - Alesund, Bergen, Geiranger, Kristiansand, Oslo, } \\
\text { Stavanger (Norway) }\end{array}$} & \multicolumn{2}{|c|}{$\begin{array}{l}\text { Port (Country) } \\
\text { - Copenhagen (Denmark) } \\
\text { - Saint Petersburg (Russia) } \\
\text { - Helsinki (Finland) } \\
\text { - Tallinn (Estonia) } \\
\text { - Kirkwall (Scotland) } \\
\text { - Vigo (Spain) } \\
\text { - Stockholm (Sweden) }\end{array}$} \\
\hline
\end{tabular}




\begin{tabular}{|l|l|l|}
\hline $\begin{array}{l}\text { Ballast water discharge is } \\
\text { forbidden while stationary } \\
\text { in port. }\end{array}$ & $\begin{array}{l}\text { Ballast water discharge is } \\
\text { forbidden while stationary in } \\
\text { port, but is permitted at a } \\
\text { distance over 50 NM and at a } \\
\text { depth of over 200 m. }\end{array}$ & $\begin{array}{l}\text { Ballast water can be } \\
\text { discharged if it originates } \\
\text { from the North Sea or the } \\
\text { Baltic Sea. }\end{array}$ \\
\hline $\begin{array}{l}\text { Port (Country) } \\
\text { - Dover, Liverpool, } \\
\text { Newcastle, Invergordon, } \\
\text { Greenock (The United } \\
\text { Kingdom) }\end{array}$ & $\begin{array}{l}\text { Akureyri, Reykjavik } \\
\text { (Iceland) }\end{array}$ & $\begin{array}{l}\text { Port (Country) } \\
\text { Saint Petersburg (Russia) }\end{array}$ \\
- Dublin (Ireland) \\
- Le Havre (France) \\
- Saint Peter Port \\
$\begin{array}{l}\text { (Guernsey) } \\
\text { - Copenhagen (Denmark) } \\
\text { - Helsinki (Finland) } \\
\text { - Tallinn (Estonia) } \\
\text { - Kirkwall (Scotland) } \\
\text { - Vigo (Spain) } \\
\text { - Stockholm (Sweden) }\end{array}$ & \\
\hline $\begin{array}{l}\text { * Alesund, Bergen, Kristiansand, Oslo, Stavanger, Geiranger (Norway) - The ballast } \\
\text { water discharge is forbidden in the Norwegian territorial waters. }\end{array}$ & \\
\hline
\end{tabular}

Observations:

${ }^{1}$ If there is a discharge operational emergency at a distance under $4 \mathrm{NM}$, the Technical and Maritime Operations Vice-President (VP) must be contacted, as well as the Safety VP and the Security and Environment VP, before taking any action.

${ }^{2}$ The ballast water management plan must be made available to the port authorities, if requested. There must be records kept for all ballast operations (UN IMO, 2004).

${ }^{3}$ EU SHIPSAN Act Joint Action 20122103/2016 (EC-Directorate General for Health and Food Safety, 2016).

\subsection{Waste streams in California}

\begin{tabular}{|c|c|c|c|c|}
\hline Incinerator & $\begin{array}{l}\text { Cleaning the } \\
\text { ship hull } \\
\text { (body) }\end{array}$ & $\begin{array}{l}\text { Sanding and } \\
\text { painting }\end{array}$ & Speed & Fuel emissions \\
\hline $\begin{array}{l}\text { Incinerating is } \\
\text { not allowed at a } \\
\text { distance under } \\
\text { 3NM from } \\
\text { shore. In Santa } \\
\text { Barbara no } \\
\text { burning is } \\
\text { allowed at a } \\
\text { distance under } \\
\text { 12NM from } \\
\text { shore. }\end{array}$ & $\begin{array}{l}\text { Cleaning the } \\
\text { hull is allowed, } \\
\text { but the crew } \\
\text { must follow the } \\
\text { EPA } \\
\text { instructions and } \\
\text { best } \\
\text { management } \\
\text { methods. }\end{array}$ & $\begin{array}{l}\text { Painting is } \\
\text { allowed while } \\
\text { stationed in } \\
\text { port, but } \\
\text { specific } \\
\text { instructions on } \\
\text { best } \\
\text { management } \\
\text { methods have } \\
\text { to be followed. }\end{array}$ & $\begin{array}{l}\text { Near Los } \\
\text { Angeles and } \\
\text { Long Beach } \\
\text { the } \\
\text { maximum } \\
\text { speed is } 12 \\
\text { knots. }\end{array}$ & $\begin{array}{l}0,1 \% \text { sulphur or less } \\
\text { in the Californian and } \\
\text { North America ECA } \\
\text { (Emission Control } \\
\text { Areas) waters. In the } \\
\text { San Diego port, } \\
\text { opacity emissions } \\
\text { must not exceed } 20 \% \\
\text { for more than } 3 \\
\text { minutes. }\end{array}$ \\
\hline
\end{tabular}




\begin{tabular}{|l|l|l|l|}
\hline Electricity & Incinerator ash & $\begin{array}{l}\text { Alkaline } \\
\text { batteries }\end{array}$ & $\begin{array}{l}\text { National Marine } \\
\text { Sanctuaries }\end{array}$ \\
\hline $\begin{array}{l}\text { While stationed } \\
\text { in port, the } \\
\text { cruise ships are } \\
\text { required to use } \\
\text { electricity from } \\
\text { land-based } \\
\text { sources. }\end{array}$ & $\begin{array}{l}\text { Considered hazardous } \\
\text { waste in California; } \\
\text { before being considered } \\
\text { ordinary waste, specific } \\
\text { requirements must be } \\
\text { met. }\end{array}$ & $\begin{array}{l}\text { The batteries are } \\
\text { collected in } \\
\text { labelled } \\
\text { containers and } \\
\text { discharged as } \\
\text { universal waste in } \\
\text { California. }\end{array}$ & $\begin{array}{l}\text { It ischarge: engine } \\
\text { cooling water, generator } \\
\text { cooling water, clean } \\
\text { bilge water and the water } \\
\text { used to wash the anchor. }\end{array}$ \\
\hline
\end{tabular}

\begin{tabular}{|l|l|l|l|l|}
\hline $\begin{array}{l}\text { Purification } \\
\text { system water } \\
\text { discharge }\end{array}$ & $\begin{array}{l}\text { Purification } \\
\text { system bio- } \\
\text { waste (sludge) }\end{array}$ & $\begin{array}{l}\text { Treated bilge } \\
\text { water }\end{array}$ & Food waste & Ballast water $^{\mathbf{1}}$ \\
\hline $\begin{array}{l}\text { Discharge can } \\
\text { only take place } \\
\text { at a distance } \\
\text { over 4NM, at a } \\
\text { speed of over 6 } \\
\text { nodes. }\end{array}$ & $\begin{array}{l}\text { Discharge can } \\
\text { only take place } \\
\text { at a distance } \\
\text { over 12NM, at } \\
\text { a speed of over } \\
\text { 6 nodes. }\end{array}$ & $\begin{array}{l}\text { Discharge can } \\
\text { only take place } \\
\text { at a distance } \\
\text { over 12NM, at } \\
\text { a speed of over } \\
\text { 6 nodes. }\end{array}$ & $\begin{array}{l}\text { Discharge can } \\
\text { only take } \\
\text { place at a } \\
\text { distance over } \\
\text { 12NM, at a } \\
\text { speed of over } \\
\text { 6 nodes. }\end{array}$ & $\begin{array}{l}\text { Ballast water } \\
\text { cannot be changed } \\
\text { or discharged } \\
\text { untreated into port } \\
\text { waters unless it } \\
\text { originated from Los } \\
\text { Angeles or the } \\
\text { Long Beach Port. }\end{array}$ \\
\hline
\end{tabular}

Observations:

${ }^{1}$ The California State Land Commission Ballast Water Management and the Port of Long Beach and Port of Los Angeles Vessel Discharge Rules and Regulations must be followed. All vessels carrying ballast water entering Californian ports must submit an annual reporting form on Hull Husbandry.

- Ship body (hull) cleaning records must be kept for the California State Land Commission Hull Husbandry Reporting Form.

- Use California Air Resources Board - Ocean-Going Vessel (OGV) Fuel Regulation (California EPA, 2016).

\subsection{Waste streams in the Mediterranean Sea}

\begin{tabular}{|l|l|l|l|}
\hline Port & Treated bilge water & Food waste & $\begin{array}{l}\text { Ballast } \\
\text { water }\end{array}$ \\
\hline All ports & $\begin{array}{l}\text { Discharge can only take } \\
\text { place at a distance over } \\
\text { 12NM, at a speed of } \\
\text { over 6 nodes. }\end{array}$ & $\begin{array}{l}\text { Discharge is allowed only if the } \\
\text { waste has been minced/chopped to } \\
\text { less than } 25 \mathrm{~mm} \text {. The discharge can } \\
\text { only take place at a distance over } \\
\text { 12NM, at a speed of over 6 nodes. }\end{array}$ & $\begin{array}{l}\text { Not } \\
\text { allowed }\end{array}$ \\
\hline $\begin{array}{l}\text { Port } \\
\text { (Country) }\end{array}$ & $\begin{array}{l}\text { Purification system } \\
\text { bio-waste (sludge) }\end{array}$ & Pool and spa water & Fireworks \\
\hline All ports & $\begin{array}{l}\text { Discharge can only take } \\
\text { place at a distance over }\end{array}$ & $\begin{array}{l}\text { Only after dichlorination. Discharge } \\
\text { can take place at a distance over } \\
\text { 12NM, at a speed of over 6 nodes. }\end{array}$ & $\begin{array}{l}\text { Not } \\
\text { allowed at } \\
\text { a distance }\end{array}$ \\
\hline
\end{tabular}




\begin{tabular}{|c|c|c|c|c|}
\hline \multicolumn{2}{|c|}{$\begin{array}{l}\text { 12NM, at a speed of } \\
\text { over } 6 \text { nodes. }\end{array}$} & & & $\begin{array}{l}\text { under } 12 \\
\text { NM from } \\
\text { shore. }\end{array}$ \\
\hline \multicolumn{5}{|c|}{ Cleaning the ship hull (body) } \\
\hline \multicolumn{5}{|c|}{ Not allowed } \\
\hline \\
\hline \multicolumn{5}{|c|}{ Washing the deck and the ship exterior } \\
\hline $\begin{array}{l}\text { Washing is only allowed with } \\
\text { the permission of the port } \\
\text { authorities and using drinkable } \\
\text { water. }\end{array}$ & \multicolumn{2}{|c|}{$\begin{array}{l}\text { Washing is only allowed with } \\
\text { drinkable water }\end{array}$} & \multicolumn{2}{|c|}{ Not allowed } \\
\hline $\begin{array}{l}\text { Port (Country) } \\
\text { - Barcelona (Spain) } \\
\text { - Catania (Italy) }\end{array}$ & \multicolumn{2}{|c|}{$\begin{array}{l}\text { Port (Country) } \\
\text { - } \text { Dubrovnik (Croatia) } \\
\text { - } \text { Corfu, Heraklion, Katakolo, } \\
\text { Mykonos, Piraeus, Rhodes } \\
\text { (Greece) } \\
\text { - La Spezia, Venice, Naples } \\
\text { (Italy) }\end{array}$} & \multicolumn{2}{|c|}{$\begin{array}{l}\text { Port (Country) } \\
\text { - Palma (Spain) } \\
\text { - Villefranche (France) } \\
\text { - Santorini (Greece) } \\
\text { - Valletta (Malta) } \\
\text { - Kusadasi (Turkey) }\end{array}$} \\
\hline \multicolumn{5}{|c|}{ * Ibiza (Spain) - Only allowed using a particular bio-degradable soap. } \\
\hline \multicolumn{5}{|c|}{ Incinerator } \\
\hline \multicolumn{5}{|c|}{ Forbidden at a distance under 3NM from shore. } \\
\hline \multicolumn{5}{|c|}{ All ports } \\
\hline \multicolumn{5}{|c|}{$\begin{array}{l}\text { Purification system water discharge } \\
\end{array}$} \\
\hline \multicolumn{2}{|c|}{$\begin{array}{l}\text { Discharge can only take place at a distance } \\
\text { over } 4 \mathrm{NM} \text {, at a speed of over } 6 \text { nodes. }\end{array}$} & \multicolumn{3}{|c|}{$\begin{array}{l}\text { The discharge can only take place at a } \\
\text { distance over } 6 \mathrm{NM} \text {, at a speed of over } 6 \\
\text { nodes. }\end{array}$} \\
\hline \multicolumn{2}{|c|}{$\begin{array}{l}\text { Port (Country) } \\
\text { - Barcelona, Ibiza, Palma (Spain) } \\
\text { - Dubrovnik (Croatia) } \\
\text { - Villefranche (France) } \\
\text { - Catania, La Spezia, Venice, Naples (Italy) } \\
\text { - Valletta (Malta) } \\
\text { - Kusadasi (Turkey) }\end{array}$} & \multicolumn{3}{|c|}{$\begin{array}{l}\text { Port (Country) } \\
\text { - Corfu, Heraklion, Katakolo, Mykonos, } \\
\text { Piraeus, Rhodes, Santorini (Greece) }\end{array}$} \\
\hline \multicolumn{5}{|c|}{ Fuel $^{3}$} \\
\hline \multicolumn{5}{|c|}{ Using fuel with $0,1 \%$ sulphur concentration in port. } \\
\hline \multicolumn{5}{|c|}{ All ports } \\
\hline \multicolumn{5}{|c|}{ Sanding and painting } \\
\hline $\begin{array}{l}\text { Sanding and abrasion actions } \\
\text { are not allowed. Painting is } \\
\text { only allowed with approval of } \\
\text { the Harbour Master. Only } \\
\text { finishing actions are } \\
\text { permitted. No activity is } \\
\text { allowed while in water. } \\
\text { Port (Country) } \\
\text { - Barcelona, Ibiza (Spain) }\end{array}$ & $\begin{array}{l}\text { Painting is c } \\
\text { approval of } \\
\text { Master. Onl } \\
\text { are permitte } \\
\text { allowed whi } \\
\text { Port (Coun } \\
\text { - Palma (S }\end{array}$ & $\begin{array}{l}\text { ly allowed with } \\
\text { ne Harbour } \\
\text { finishing actions } \\
\text { No activity is } \\
\text { in water. } \\
\text { y) } \\
\text { ain) }\end{array}$ & $\begin{array}{l}\text { Sanding and } \\
\text { actions are n } \\
\text { Painting is or } \\
\text { small surface } \\
\text { the port auth } \\
\text { permission. } \\
\text { Port (Count } \\
\text { - Corfu, He } \\
\text { Katakolo, } \\
\text { Rhodes, S } \\
\text { (Greece) }\end{array}$ & $\begin{array}{l}\text { orasion } \\
\text { allowed. } \\
\text { y allowed on } \\
\text { and requires } \\
\text { ities' } \\
\text { y) } \\
\text { klion, } \\
\text { tykonos, } \\
\text { thorini }\end{array}$ \\
\hline
\end{tabular}




\begin{tabular}{|c|c|c|c|}
\hline $\begin{array}{l}\text { Sanding and abrasion actions } \\
\text { are not allowed. Painting is } \\
\text { allowed on small surfaces and } \\
\text { requires the approval of the } \\
\text { Harbour Master. No activity is } \\
\text { allowed while in water. } \\
\text { Port (Country) } \\
\text { - Civitavecchia (Italy) }\end{array}$ & \multicolumn{2}{|c|}{$\begin{array}{l}\text { Painting requires the approval } \\
\text { of the Harbour Master and can } \\
\text { only be done on small } \\
\text { surfaces. No activity is } \\
\text { allowed while in water. } \\
\text { Port (Country) } \\
\text { - Venice (Italy) }\end{array}$} & $\begin{array}{l}\text { Painting is only allowed on } \\
\text { small surfaces and requires } \\
\text { an approval from the port } \\
\text { authorities. } \\
\text { Port (Country) } \\
\text { - La Spezia (Italy) }\end{array}$ \\
\hline \multicolumn{2}{|c|}{$\begin{array}{l}\text { Allowed. Precautions must be taken to } \\
\text { prevent discharges into water. } \\
\text { Port (Country) } \\
\text { - Valletta (Malta) }\end{array}$} & \multicolumn{2}{|c|}{$\begin{array}{l}\text { Not allowed: } \\
\text { Port (Country) } \\
\text { - Dubrovnik (Croatia) } \\
\text { - Villefranche (France) } \\
\text { - Piraeus (Greece) } \\
\text { - Catania, Naples (Italy) } \\
\text { - Kusadasi (Turkey) } \\
\end{array}$} \\
\hline
\end{tabular}

Observations:

${ }^{1}$ Records for all ballast operations must be kept (UN IMO, 2004).

${ }^{2}$ The purification system water discharge is prohibited in the port. If the discharge needs to happen at a distance under 4 NM from shore, the crew must first contact the Technical and Maritime Operations VP, the Safety, Security and Environment VP (UN IMO, 2011).

${ }^{3}$ The fuel used on these routes, including between ports, should contain under $1.5 \%$ sulphur (UN IMO, 2011).

\section{Tenerife) \\ 4.7. Waste streams over the Atlantic (with reference to Antigua, Malaga and}

\begin{tabular}{|c|c|c|c|c|c|c|c|}
\hline $\begin{array}{l}\text { Port } \\
\text { (country) }\end{array}$ & $\begin{array}{l}\text { Purification } \\
\text { system water } \\
\text { discharge }^{1}\end{array}$ & \multicolumn{2}{|c|}{$\begin{array}{l}\text { Treatment } \\
\text { system bio- } \\
\text { residue (sludge) }\end{array}$} & \multicolumn{2}{|c|}{$\begin{array}{l}\text { Treated bilge } \\
\text { water }\end{array}$} & \multicolumn{2}{|c|}{ Food waste } \\
\hline All ports & $\begin{array}{l}\text { Discharge can } \\
\text { only take } \\
\text { place at a } \\
\text { distance over } \\
4 \mathrm{NM} \text {, at a } \\
\text { speed of over } \\
6 \text { nodes. }\end{array}$ & \multicolumn{2}{|c|}{$\begin{array}{l}\text { Discharge can } \\
\text { only take place at } \\
\text { a distance over } \\
\text { 12NM, at a speed } \\
\text { of over } 6 \text { nodes. }\end{array}$} & & $\begin{array}{l}\text { harge can } \\
\text { take } \\
\text { e at a } \\
\text { ince over } \\
\text { M, at a } \\
\text { d of over } \\
\text { des. }\end{array}$ & \multicolumn{2}{|c|}{$\begin{array}{l}\text { If the waste was } \\
\text { shredded to less than } \\
25 \mathrm{~mm} \text {, discharge can } \\
\text { take place at a distance } \\
\text { over } 12 \mathrm{NM} \text {, at a speed } \\
\text { of over } 6 \text { nodes. }\end{array}$} \\
\hline $\begin{array}{l}\text { Port } \\
\text { (country) }\end{array}$ & \multicolumn{2}{|c|}{ Pool and spa water } & \multicolumn{2}{|c|}{ Fireworks } & \multicolumn{2}{|c|}{ Ballast water $^{2}$} & $\begin{array}{l}\text { Authorized } \\
\text { incinerator }\end{array}$ \\
\hline All ports & \multicolumn{2}{|c|}{$\begin{array}{l}\text { Only after } \\
\text { dichlorination. The } \\
\text { discharge can take } \\
\text { place at a distance over } \\
\text { 12NM, at a speed of } \\
\text { over } 6 \text { nodes. }\end{array}$} & \multicolumn{2}{|c|}{$\begin{array}{l}\text { Not allowed at } \\
\text { a distance } \\
\text { under 12NM } \\
\text { from shore. }\end{array}$} & \multicolumn{2}{|c|}{$\begin{array}{l}\text { Discharge not } \\
\text { allowed. }\end{array}$} & $\begin{array}{l}\text { Burning actions } \\
\text { are not allowed in } \\
\text { the port or at a } \\
\text { distance under } \\
\text { 3NM from shore. }\end{array}$ \\
\hline $\begin{array}{l}\text { Port } \\
\text { (Country) } \\
\end{array}$ & \multicolumn{3}{|c|}{\begin{tabular}{l|l} 
Cleaning the & W \\
ship hull (body) & dec
\end{tabular}} & \multicolumn{4}{|c|}{ Sanding and painting } \\
\hline
\end{tabular}




\begin{tabular}{|l|l|l|l|}
\hline $\begin{array}{l}\text { St. John's } \\
\text { (Antigua) }\end{array}$ & $\begin{array}{l}\text { Allowed with the } \\
\text { port authorities } \\
\text { approval. }\end{array}$ & $\begin{array}{l}\text { Allowed only } \\
\text { with potable } \\
\text { water. }\end{array}$ & $\begin{array}{l}\text { Sanding and abrasion actions are not } \\
\text { allowed. Painting is only allowed on } \\
\text { small surfaces and requires the port } \\
\text { authorities's permission. No activity is } \\
\text { allowed while in water. }\end{array}$ \\
\hline Málaga & Not allowed & $\begin{array}{l}\text { Allowed only } \\
\text { with potable } \\
\text { water and } \\
\text { phosphate-free } \\
\text { detergents. }\end{array}$ & $\begin{array}{l}\text { Sanding and abrasion actions are not } \\
\text { allowed. Painting is only allowed on } \\
\text { small surfaces and requires the port } \\
\text { authorities's permission. No activity is } \\
\text { allowed while in water. }\end{array}$ \\
\hline Tenerife & Not allowed & $\begin{array}{l}\text { Allowed only } \\
\text { with potable } \\
\text { water and } \\
\text { phosphate-free } \\
\text { detergents. }\end{array}$ & $\begin{array}{l}\text { Sanding and abrasion actions are not } \\
\text { allowed. Painting is only allowed on } \\
\text { small surfaces and requires the port } \\
\text { authorities's permission. No activity is } \\
\text { allowed while in water. }\end{array}$ \\
\hline
\end{tabular}

Observations:

${ }^{1}$ The purification system water discharge is prohibited in the port. If the discharge needs to happen at a distance under 4 NM from shore, the crew must first contact the Technical and Maritime Operations VP, the Safety, Security and Environment VP (UN IMO, 2011)

${ }^{2}$ Records for all ballast operations must be kept. The exchange of the ships' ballast water must be made on the route at a distance of at least 200NM from shore, in an area with a water depth of at least $200 \mathrm{~m}$ or if operationally impossible, the exchange can be done closer to shore but not at a distance under 50NM and only in waters with a depth of at least $200 \mathrm{~m}$. The ballast tank sediments must be discharged at a distance of at least 200NM from shore.

\subsection{Waste streams over the Atlantic (with reference only to New York, Boston and Sydney, Nova Scotland, Canada)}

\begin{tabular}{|l|l|l|l|}
\hline $\begin{array}{l}\text { Port } \\
\text { (country) }\end{array}$ & $\begin{array}{l}\text { Purification system water } \\
\text { discharge }\end{array}$ & Treated bilge water & Ballast water \\
\hline $\begin{array}{l}\text { New York } \\
\text { CSA) }\end{array}$ & $\begin{array}{l}\text { Can be unloaded and transferred to } \\
\text { an appropriate vendor while the } \\
\text { ship is at berth. }\end{array}$ & $\begin{array}{l}\text { Discharge can only } \\
\text { take place at a } \\
\text { distance over 12NM, } \\
\text { at a speed of over 6 } \\
\text { nodes. }\end{array}$ & Not allowed \\
\hline $\begin{array}{l}\text { Boston } \\
\text { (USA) }\end{array}$ & $\begin{array}{l}\text { Transferred while at berth to a } \\
\text { licensed company. }\end{array}$ & $\begin{array}{l}\text { The discharge can } \\
\text { only take place at a } \\
\text { distance over 12NM, } \\
\text { at a speed of over 6 } \\
\text { nodes. }\end{array}$ & Not allowed \\
\hline $\begin{array}{l}\text { Sydney, } \\
\text { Nova } \\
\text { Scotland } \\
\text { (Canada) }\end{array}$ & $\begin{array}{l}\text { Transferred while at berth to a } \\
\text { licensed company. }\end{array}$ & $\begin{array}{l}\text { The discharge can } \\
\text { only take place at a } \\
\text { distance over 12NM, } \\
\text { at a speed of over 6 } \\
\text { nodes. }\end{array}$ & Not allowed \\
\hline
\end{tabular}




\begin{tabular}{|c|c|c|c|c|}
\hline $\begin{array}{l}\text { Port } \\
\text { (Country) }\end{array}$ & $\begin{array}{l}\text { Cleaning the ship hull } \\
\text { (body) }\end{array}$ & $\begin{array}{l}\text { Washing the } \\
\text { deck and ship } \\
\text { exterior }\end{array}$ & $\begin{array}{l}\text { Sanding } \\
\text { and } \\
\text { painting }\end{array}$ & Incinerator \\
\hline $\begin{array}{l}\text { New } \\
\text { York } \\
\text { (USA) }\end{array}$ & $\begin{array}{l}\text { Cleaning the ship hull with } \\
\text { the help of divers is allowed, } \\
\text { but the crew is required to } \\
\text { demand port access and } \\
\text { present the TWIC } \\
\text { (Transportation Worker } \\
\text { Identification Credential) } \\
\text { approval. }\end{array}$ & $\begin{array}{l}\text { Allowed with } \\
\text { potable water. }\end{array}$ & $\begin{array}{l}\text { Allowed. } \\
\text { Sanding the } \\
\text { exterior } \\
\text { while } \\
\text { stationary } \\
\text { in water not } \\
\text { allowed. }\end{array}$ & $\begin{array}{l}\text { Burning } \\
\text { actions are not } \\
\text { allowed at a } \\
\text { distance under } \\
3 \mathrm{NM} \text { from } \\
\text { shore or while } \\
\text { the ship is } \\
\text { moored. }\end{array}$ \\
\hline $\begin{array}{l}\text { Boston } \\
\text { (USA) }\end{array}$ & $\begin{array}{l}\text { Permission required from the } \\
\text { port authorities. }\end{array}$ & $\begin{array}{l}\text { Allowed with } \\
\text { potable water. }\end{array}$ & $\begin{array}{l}\text { Permission } \\
\text { required. }\end{array}$ & $\begin{array}{l}\text { Burning } \\
\text { actions are not } \\
\text { allowed at a } \\
\text { distance under } \\
3 \mathrm{NM} \text { from } \\
\text { shore or while } \\
\text { the ship is } \\
\text { moored. }\end{array}$ \\
\hline $\begin{array}{l}\text { Sydney, } \\
\text { Nova } \\
\text { Scotia } \\
\text { (Canada) }\end{array}$ & Allowed & Allowed & Allowed & $\begin{array}{l}\text { Burning } \\
\text { actions are not } \\
\text { allowed at a } \\
\text { distance under } \\
3 \mathrm{NM} \text { from } \\
\text { shore or while } \\
\text { the ship is } \\
\text { moored. }\end{array}$ \\
\hline
\end{tabular}

Observations:

- A record of all ballast operations must be kept. The ship's ballast water exchange must be made at a distance of at least 200NM away from shore, in waters at least 200m deep or, if operationally impossible, the exchange can be done closer, but not under 50NM in waters at least $200 \mathrm{~m}$ deep. Ballast tank sediments must be discharged at a distance of 200NM from shore (US EPA, 2013).

- It is forbidden to discharge the purification system water into the port. If it is necessary to make the water discharge at a distance under 4NM from shore, the Technical and Marine Operations VP, as well as the VP of Safety, Security and the Environment should be contacted before taking any action (UN IMO, 2011).

\section{Conclusions}

The Disney Cruise Line Company aims to minimize the environmental impact of cruise ships by focusing on the use of new technologies, increasing energy efficiency, reducing the amount of generated waste, educating employees and customers, while promoting environmental conservation around the world. In 2013, Disney Cruise Line was declared the world's most environmentally responsible cruise line. The company complies with all national and international environmental conventions, laws and regulations. 
The following potentially-polluting elements and activities, which can be considered to be pollution indicators, are strictly regulated by the DCL company in order to ensure that their environmental impact is as low as possible: discharging water and bio-residue (sludge) from the purification system; unloading treated bilge water; discharging ballast water; incineration; cleaning the incinerator chimney; incinerator ash; alkaline batteries; ship painting and polishing; used fuel; fuel emissions; opacity; washing the ship and the ship bridge; unloading food waste; unloading pool and spa water; fireworks.

The key words underpinning DLC's eco-friendly approach to its activity are: keeping records, monitorization, verification, awareness, constant communication.

\section{References}

1.Balaji R., Yaakob O., Koh K.K., 2014. A review of developments in ballast water management, Environmental Reviews, 22:3, p.298-310, DOI: 10.1139/er-2013-0073

2.Burgin S., Hardiman N., 2011. The direct physical, chemical and biotic impacts on Australian coastal waters due to recreational boating, Biodiversity And Conservation, 20:4, p.683-701, DOI: $10.1007 / \mathrm{s} 10531-011-0003-6$

3.California Environmental Protection Agency - California Air Resources Board, 2016. The California Ocean-Going Vessel (OGV) Fuel Regulation, California: Government Printing Office.

4.Disney Cruise Line site, https://disneycruise.disney.go.com/

5.Disney Cruise Line, 2016. Safety Management System, Environmental Aspects, England: Magical Cruise Company Limited

6.Elks J., 2013. Disney Scores the Only "A” on Cruise Industry Environmental Report Card, http://www.sustainablebrands.com/news and_views/communications/jennifer-elks/disneyscores-only-cruise-industry-environmental-report-

7.European Commission - Directorate General for Health and Food Safety, 2016. European Manual for Hygiene Standards and Communicable Disease Surveillance on Passenger Ships (EU Shipsan Act Joint Action 20122103). Second edition, Larissa, Greece, http://www.shipsan.eu/KeyResources.aspx

8.Kizielewicz J., Lukovic T., 2015. Negative Impact of Cruise Tourism Development on Local Community and the Environment, Information, Communication and Environment: Marine Navigation and Safety of Sea Transportation, p.243-250

9.Lasserre F., Tetu P.L., 2015. The cruise tourism industry in the Canadian Arctic: analysis of activities and perceptions of cruise ship operators, Polar Record, 51:1, p.24-38, DOI: $10.1017 / \mathrm{S} 0032247413000508$

10.Loehr L.C., Ehrman H., Atkinson M., George K., Beegle-Krause C.J., 2003. Using a simple dilution model to estimate wastewater contaminant concentrations behind moving passenger vessels, OCEANS 2003 MTS/IEEE: Conference on Celebrating the Past - Teaming Toward the Future, p. 390-393

11.Morehouse C., Koch D., 2003. Alaska's cruise ship initiative and the commercial passenger vessel environmental compliance program, OCEANS 2003 MTS/IEEE: Conference on Celebrating the Past - Teaming Toward the Future, p.372-375

12.Papaefthimiou S., Maragkogianni A., Andriosopoulos K., 2016. Evaluation of cruise ships emissions in the Mediterranean basin: The case of Greek ports, International Journal of Sustainable Transportation, 10:10, p.985-994, DOI: 10.1080/15568318.2016.1185484

13.Srinivasan M., Swain G.W., 2007. Managing the use of copper-based antifouling paints,Environmental Management, 39:3, p.423-441, DOI: 10.1007/s00267-005-0030-8

14.The Alaska Department of Environmental Conservation - Division of Air Quality, 2014. Air Quality Control. 18 AAC 50.070, Alaska: Government Printing Office. 
15.The Alaska Department of Environmental Conservation - Division of Water, 2014. The Large Commercial Passenger Vessel Wastewater Discharge General Permit. 18 AAC 70.005, Alaska: Government Printing Office.

16.Tichavska M., Tovar B., 2015. Port-city exhaust emission model: An application to cruise and ferry operations in Las Palmas Port, Transportation Research Part A-Policy and Practice, Vol.78, p.347-360, DOI: 10.1016/j.tra.2015.05.021

17.Ulnikovic V.P., Vukic M., Nikolic R., 2012. Assessment of vessel-generated waste quantities on the inland waterways of the Republic of Serbia, Journal Of Environmental Management, Vol.97, p.97101, DOI: 10.1016/j.jenvman.2011.11.003

18.United Nations - International Maritime Organization, 2004. International Convention for the Control and Management of Ships' Ballast Water and Sediments, IMO Publishing, http://www.bsh.de/de/Meeresdaten/Umweltschutz/Ballastwasser/Konvention_en.pdf

19.United Nations - International Maritime Organization, 2011. International Convention for the Prevention of Pollution from Ships (MARPOL), 5th edition, IMO Publishing.

20.Universal Waste site, https://www.epa.gov/hw/universal-waste

21.U.S. Department of Health and Human Services - U.S. Public Health Service Centers for Disease Control and Prevention/National Center for Environmental Health, 2011. Vessel Sanitation Program, Florida.

22.U.S. Environmental Protection Agency, 1990. Clean Air Act, Washington, DC: U.S. Government Printing Office.

23.U.S. Environmental Protection Agency - National Pollutant Discharge Elimination System, 1972. Federal Water Pollution Control Act Amendments (Clean Water Act) 33 USC 1251 et seq, Washington, DC: U.S. Government Printing Office.

24.U.S. Environmental Protection Agency (EPA) - National Pollutant Discharge Elimination System (NPDES), 2013. Vessel General Permit for Discharges Incidental to the Normal Operation of Vessels (VGP), Washington, DC: U.S. Government Printing Office, https://www3.epa.gov/npdes/pubs/vgp_permit2013.pdf

25.Verna D.E., Harris B.P., 2016. Review of ballast water management policy and associated implications for Alaska, Marine Policy, Vol.70, p.13-21, DOI: 10.1016/j.marpol.2016.04.024 